\title{
PRZESTRZENIE ZDZIWIENIA W TEKSTACH PODRÓŻNICZYCH MICHALA TYSZKIEWICZA I JÓZEFA IGNACEGO KRASZEWSKIEGO
}

Słowa kluczowe: podróż, Ch. Darwin, J.I. Kraszewski, M. Tyszkiewicz, zdziwienie

Keywords: travel, Ch. Darwin, J.I. Kraszewski, M. Tyszkiewicz, surprise

\section{Podróż: zdziwienie i poznanie}

Wiek XIX był to czas wielkich podróżników i naukowych ekspedycji. Ich zadaniem było profesjonalne poszerzanie wiedzy, które zresztą w różnych formach od zawsze towarzyszyło podróżom ${ }^{1}$. Dziewiętnastowieczni wędrowcy mieli tworzyć obraz nieznanego świata na mapach, obrazach, litografiach, w dziennikach i opisach swoich peregrynacji.

Anna Wieczorkiewicz wskazuje na związek, jaki łączy sposób postrzegania świata przez podróżnika z przyjętą w jego epoce metodą pozyskiwania wiedzy². Chciałabym zwrócić uwagę na jeden aspekt procesu poznawczego - zdziwienie. Poprzedza ono akt poznania, zmusza do podjęcia refleksji i zadawania pytań. Żeby podróż była przygodą poznawczą, podróżnik musi się dziwić. Za wyróżnik poznania w podróży można uznać kategorię zdziwienia w rozumieniu Arystotelesa:

Dzięki bowiem dziwieniu się ludzie obecni, jak i pierwsi myśliciele, zaczęli filozofować; dziwiły ich początkowo niezwykłe zjawiska spotykane codziennie, później z wolna stawali wobec trudniejszych zagadnień, jak na przykład wobec zjawisk związanych z Księżycem, Słońcem i gwiazdami. A kto jest bezradny i dziwi się, poznaje swoją niewiedzę. (Dlatego nawet miłośnik mitów jest w pewnym sensie miłośnikiem mądrości, bo mit jest pełen dziwów) ${ }^{3}$.

${ }^{1}$ Wystarczy wspomnieć renesansowe podróże humanistów czy XVIII-wieczną grand tour. Anna Wieczorkiewicz przypomina o XVI-wiecznej ars apodemica, w ramach której odzróżniano szlachetne peregrinari (podróż, której celem była nauka) od vagari (bezcelowego włóczęgostwa). Vide Anna Wieczorkiewicz, Apetyt turysty: o doświadczaniu świata w podróży (Kraków: Universitas, 2008), 98.

${ }^{2}$ Ibidem.

${ }^{3}$ Arystoteles, Metafizyka, trans. Kazimierz Leśniak (Warszawa: PWN, 1983), 8. 
Postanowiłam zbadać dziewiętnastowieczne przestrzenie zdziwienia na przykładzie dwóch tekstów, zdradzających metodę pozyskiwania wiedzy o świecie, a spisanych przez turystę-archeologa (Michała Tyszkiewicza) i turystę-literata (Józefa Ignacego Kraszewskiego). Prezentują one różne strategie poznawcze, a jednocześnie są przykładem relacji spisanych przez profesjonalistów w ich dziedzinach. Postaram się odpowiedzieć na pytanie, co dziwiło omawianych autorów podczas podróży i jak to zdziwienie wpływało na formę zapisu doświadczenia. Interesują mnie zwłaszcza stworzone przez nich opisy przestrzeni, czyli: „[...] terytorium, na jakim rozwijają się zdarzenia, różne wycinki tego terytorium [...] wreszcie przedmioty naturalne i wytworzone oraz zjawiska przyrody [...]"4. Zamierzam scharakteryzować mapy opisanych przez autorów terytoriów oraz określić zbiory, które ze sobą przywieźli, a wreszcie odpowiedzieć na pytanie, jak doświadczenie poznawcze podróży zmieniło ich porządek świata.

Autorytetem dla dziewiętnastowiecznych podróżników pozostawał jeden z ostatnich erudytów, Alexander von Humboldt, który w relacjach z wypraw do Ameryki Południowej i w głąb Rosji łączył analizy z opisem wrażeń i emocji ${ }^{5}$. To właśnie doświadczenia podróżnicze legły u podstaw pomysłu Humboldta, by w jednym dziele (Kosmosie) zebrać całą dostępną wiedzę na temat świata materialnego ${ }^{6}$.

Wiek XIX był jednak okresem postępującej specjalizacji, choć z drugiej strony wielu autorów (również bohaterowie tego artykułu) przekraczało granice swoich dyscyplin (to samo dotyczy opisu podróży jako gatunku - Anna Zdanowicz zauważa, że ówcześni badacze literatury sytuowali go między beletrystyką a literaturą naukową $\left.{ }^{7}\right)$. Autorem tekstu pionierskiego ${ }^{8}$, który narzucił wielu późniejszym autorom sposób patrzenia na świat, był poszukiwacz gatunków ${ }^{9}$

\footnotetext{
${ }^{4}$ Henryk Markiewicz, Wymiary dzieła literackiego (Kraków: Universitas, 1996), 147.

${ }^{5}$ Vide Andrea Wulf, Człowiek, który zrozumiał naturę. Nowy świat Alexandra von Humboldta, trans. Katarzyna Bażyńska-Chojnacka, Piotr Chojnacki (Poznań: Wydawnictwo Poznańskie, 2017), 25.

${ }^{6}$ Oczywiście Alexander von Humboldt nie był w stanie zebrać wszystkich informacji w pojedynkę. W tym celu uruchomił sieć kontaktów z badaczami na całym świecie, którzy nadsyłali mu efekty swoich obserwacji. Do jego korespondentów należał też Wincenty Pol, u którego romantyczne tradycje literackie ścierały się ze scjentystyczną fascynacją geografią. Vide Małgorzata Łoboz, „Geograf zabija powoli poetę... - Wincentego Pola Obrazy z życia i natury (1869-1870)”, in Podróż i literatura 1864-1914, ed. Ewa Ihnatowicz (Warszawa: Wydział Polonistyki Uniwersytetu Warszawskiego, 2008), 118.

${ }^{7}$ Anna Zdanowicz, „Czytanie w podróży, czytanie podróży”, in Podróż i literatura 1864-1914, 542.

${ }^{8}$ Relacja Darwina nie jest oczywiście oderwana od dzieł poprzedników - wręcz przeciwnie: tekst został naszpikowany odwołaniami do innych autorów, zarówno naukowców, jak i pisarzy. Wśród nich pierwsze miejsce zajmują wspomniany Alexander von Humboldt oraz przyjaciel i mentor przyrodnika, Charles Lyell, autor rewolucyjnej pracy z zakresu geologii.

${ }^{9}$ Kategorią tą posługuje się Richard Conniff w odniesieniu do badaczy natury pozyskujących swoje zbiory w terenie. Vide Richard Conniff, Poszukiwacze gatunków. Bohaterowie, głupcy i szalony pościg, by zrozumieć życie na ziemi, trans. Zofia Łomnicka (Warszawa: Prószyński Media, 2011).
} 
Charles Darwin, podróżujący w latach 1831-1836 na okręcie Beagle. Cel Podróży naturalisty to zapoznanie czytelników z florą, fauną i geologią odwiedzanych krain. Cechą psychologiczną autora była umiejętność szybkiego rozpoznawania anomalii ${ }^{10}$, czyli obiektów budzących zdziwienie uczonych. Podróż naturalisty, tak istotną w dziewiętnastowieczności, czynię punktem odniesienia dla poznawczych podróży Kraszewskiego i Tyszkiewicza (nie sugerując przy tym wpływu Darwina na tych autorów).

\section{Podróżnik}

Józef Ignacy Kraszewski był samotnym wędrowcem po bezdrożach polskiej wsi. Wydane w 1840 roku Wspomnienia Wołynia, Polesia i Litwy były pokłosiem pięciu podróży, z których pierwszą pisarz odbył w 1834 roku ${ }^{11}$ (a więc w czasie, gdy podróż Darwina miała się ku końcowi). Pisarz dowiódł, że nie trzeba wcale udawać się w egzotyczne strony, żeby doświadczyć zdziwienia. Równie owocna mogła okazać się podróż po swojszczyźnie. Egzotyzm w literaturze był często przedmiotem ataków rodzimej krytyki ${ }^{12}$. Pokolenie romantyków poczytywało sobie za obowiązek zwiedzać i opisywać także rodzime strony oraz badać kulturę ludową. Z tego obowiązku w sposób oryginalny wywiązał się właśnie Kraszewski jako autor Wspomnień Wolynia, Polesia i Litwy, utworu łączącego różne typy podróżniczej narracji - od reportażu, przez malowniczy obraz po szkic historyczny. Wspomnienia... z jednej strony reprezentują typ podróży krajoznawczej, a $z$ drugiej - są zapisem z wyprawy w nieznane. Pisarz od początku porównywał swoją podróż do wypraw wielkich odkrywców:

Gdy gdzieindziej potrzeba dla odkrycia nowych i nieopisanych krain, płynąć jak Ross przez lody, lub iść do źródeł Nilu gdzie już tylu zginęło; kiedy gdzieindziej podróżni zmuszeni są bardzo dawno wiadome, widziane, opisane, oklepane rzeczy powtarzać coraz na inszy sposób, kiedy już aż do znudzenia wymalowane są, objaśnione, upoetyzowane i brzegi Renu i góry Szkocji i biedne chaty wieśniaków Irlandii, (gorsze daleko od naszych); kiedy nowych zwierząt naturaliści szukać muszą w głębi ziemi (mammuty) nowych roślin na dnie morza (algi); - u nas w krajach słowiańskich, wszystko jest jeszcze w stanie dziewiczym, do opisu, do wynalezienia, i odkrycia przed światem. Stern czy Palllas, Humboldt czy Miss Trollope, Basil-Hall i Xże Puckler-Muskau, każdy by tu swój rodzaj podróży mógł z korzyścią przedsięwziąć, do każdej $\mathrm{z}$ nich znajdują się jeszcze nietknięte materiały ${ }^{13}$.

${ }^{10}$ Gillian Beer, „Przyjemność jak tragedia: wyobraźnia a rzeczywistość materialna”, Teksty Drugie, no. 3 (2011): 137.

${ }^{11}$ Stanisław Burkot, „Podróż po stronach rodzinnych”, in Józef Ignacy Kraszewski, Wspomnienia Wotynia, Polesia i Litwy (Warszawa: Ludowa Spółdzielnia Wydawnicza, 1985), 11.

${ }^{12}$ Ewa Paczoska, „Przeciw podróży”, in Podróż i Literatura..., 592.

${ }^{13}$ Józef Ignacy Kraszewski, Wspomnienia Wotynia, Polesia i Litwy, vol. 1 (Wilno: T. Glückcksberg, 1840), 113. 
Zdziwienie światem zależy od przyjętej przez podróżnika perspektywy. Kraszewski patrzył na rodzime strony oczami Rossa czy Humboldta odkrywających nieznane tereny i tej strategii się trzymał, dokonując egzotyzacji znanej-nieznanej przestrzeni. Stanisław Burkot wskazuje, że deklaracja Kraszewskiego wpisywała się w nowy nurt podróży „swojaka po swojszczyźnie”, która z jednej strony miała znaczenie patriotyczne, poprzez zbieranie i opisywanie pamiątek narodowych, z drugiej budowana była na opozycji swojski-obcy ${ }^{14}$.

Katarzyna Galant, podobnie jak Stanisław Burkot, uważa Wspomnienia Wołynia, Polesia i Litwy za utwór graniczny, który inauguruje dojrzałą twórczość Kraszewskiego ${ }^{15}$. Badaczka zauważa, że pisarz przechodził tu do bardziej zindywidualizowanej i nowoczesnej formy realizmu. Rzeczywiście: Kraszewski, podróżując po swojszczyźnie, korzystał z dyliżansu pocztowego, łodzi, sypiał w przydrożnych karczmach, a każdy ze środków lokomocji, każda nowa lokalizacja stawały się punktem wyjścia do szkicu - i to również dosłownie: w wydaniu paryskim Wspomnień... pisarz zilustrował tekst własnymi grafikami. Autor nie poprzestawał jednak na szkicu, nakładał na niego siatkę podań historycznych, legend i osobistych doświadczeń. Podróże Kraszewskiego po Polesiu, Wołyniu i Litwie stały się przyczynkiem do stworzenia wspaniałej kolekcji regionalnych starożytności i osobliwości.

Hrabia Michał Tyszkiewicz łączył pasję zbieracką z zamiłowaniem do podróży i archeologii. Szczególnie popularnym celem wyprawy archeologicznej był już od czasów napoleońskich Egipt, zaliczany do kultury Orientu, który w tym okresie uosabiał to, co egzotyczne i tajemnicze ${ }^{16}$. Jako centrum wiedzy tajemnej stał się ziemią obiecaną poszukiwaczy osobliwości, do których należał niewątpliwie Michał Tyszkiewicz. Ten uczeń Adama Jochera, bibliografa i numizmatyka, posiadał środki i kompetencje do tego, by stać się jednym z największych kolekcjonerów stulecia ${ }^{17}$. Pałac w Gródku Ostroszyckim zapełnił zbiorami broni, obrazów, porcelany i szkła ${ }^{18}$.

Arystokratyczne pochodzenie, koneksje i zasobność portfela decydowały o tym, jak, z kim i gdzie podróżował Tyszkiewicz. Do Afryki płynął nowoczesnym

${ }^{14}$ Stanisław Burkot, Polskie podróżopisarstwo romantyczne (Warszawa: PWN, 1988), 240.

${ }^{15}$ Katarzyna Galant, „Droga z Wołynia do realizmu. O Wspomnieniach Wotynia, Polesia i Litwy Józefa Ignacego Kraszewskiego", in Podróże i podróżopisarstwo w polskiej literaturze i kulturze XIX wieku: studia i szkice, ed. Agnieszka Kowalczyk, Aneta Kwiatek (Kraków: Księgarnia Akademicka, 2015), 93.

${ }^{16}$ Edward Said, Orientalizm, trans. Witold Kalinowski (Warszawa: PIW, 1991), 92.

${ }^{17}$ Pasja kolekcjonerska i archeologiczna była charakterystyczna dla całego rodu Tyszkiewiczów, do którego należeli również nestorzy polskiej archeologii, bracia Eustachy i Konstanty. Ten ostatni jest autorem tekstu podróżniczo-krajoznawczego: Wilia i jej brzegi. Pod względem hydrograficznym, historycznym, archeologicznym i etnograficznym, którą ilustrował i wydał Kraszewski.

${ }^{18}$ Cecylia Gałczyńska, „Michał Tyszkiewicz: z dziejów dziewiętnastowiecznej archeologii i kolekcjonerstwa”, Archeologia, no. 59 (2008): 195-197. 
parostatkiem. Został zaproszony na prywatne zwiedzanie muzeum egipskich starożytności, otrzymał specjalne pozwolenia od miejscowych dygnitarzy na prowadzenie wykopalisk. Jego przewodnikiem był wicekonsul. W podróży nigdy nie był sam - zawsze towarzyszyli mu tragarze, turyści, robotnicy, znajomi i przedstawiciele miejscowych elit. To grupowe podróżowanie wpłynęło na formę narracji. W dzienniku zdecydowanie dominuje zaimek „my”, podczas gdy subiektywna perspektywa zaimka ,ja” jest zarezerwowana dla wyjątkowych przeżyć podróżnika.

\section{Mapa, czyli kwestia białych plam}

W opowieściach podróżniczych mapa jest tematem i figurą - czasami ukrytą, czasami jawną. Pisarze i podróżnicy mogą na podstawie map geograficznych tworzyć swoje mapy wyobrażone ${ }^{19}$ lub odwrotnie - mapy wyobrażone, zbudowane w świecie książek, poprzedzają kontakt $\mathrm{z}$ mapą geograficzną ${ }^{20}$. Pierwszy kontakt $\mathrm{z}$ mapą odciska piętno na oczekiwaniach i marzeniach wobec nieznanych miejsc - tworzy zarys przestrzeni zdziwienia. To również początek tego, co Edward Said nazywa „geografią kreacyjną" ${ }^{21}$, gdy temu, co odległe, nadajemy znaczenie emocjonalne, co pomaga nam wzmocnić obraz samego siebie $^{22}$.

Darwin zapełniał białe plamy okazami zwierząt, formacjami geologicznymi, anomaliami przyrodniczymi oraz przedstawicielami miejscowych plemion. Podkreślał, że w podróży dookoła świata najatrakcyjniejsze jest ożywienie mapy: „Mapa ziemi przestaje być martwą kartą, lecz staje się obrazem pełnym najróżnorodniejszych i najżywszych scen"23. Podróż, zdaniem Darwina, pozwala człowiekowi wyzwolić się z prowincjonalnego punktu widzenia, a słowo i obraz zamienia w ciało. Bezpośrednie przeżycie umożliwia zdziwienie się światem, którego wartość poznawcza przewyższa odartą z emocji i wrażeń kartografię.

${ }^{19}$ Vide Elżbieta Rybicka, Geopoetyka. Przestrzeń i miejsce we wspótczesnych teoriach i praktykach literackich (Warszawa: Universitas, 2014), 200-208.

${ }^{20}$ To drugie podejście było charakterystyczne dla formacji romantycznej. O prymacie przeżycia mającego źródło w lekturze nad przeżyciem bezpośrednim pisał Zygmunt Łempicki, „Świat książek i świat rzeczywisty", in idem, Renesans, Oświecenie, Romantyzm i inne studia $z$ historii kultury, trans. Bogdan Suchodolski (Warszawa: PIW, 1966), 329-368.

${ }^{21}$ Edward Said, Orientalizm, 97, 98.

${ }^{22}$ Gdyby zastosować tu perspektywę antropologii kulturowej, przy konstruowaniu takiej mapy niezwykle ważne byłyby też kategorie orbis interior i exterior, które wartościują i różnicują przestrzeń w kulturze tradycyjnej.

${ }^{23}$ Karol Darwin, Podróż naturalisty: dziennik spostrzeżeń dot. historyi naturalnej i geologii okolic, zwiedzanych podczas podróży naokoło świata na okręcie J. K. M. „Beagle” pod dow. Fitz Roy, trans. Józef Nusbaum-Hilarowicz (Warszawa: Przegląd Tygodniowy, 1887), 411. 
Marszruta Michała Tyszkiewicza była typowa dla XIX-wiecznych podróżników odwiedzających Egipt ${ }^{24}$. Hrabia przybył do Egiptu w roku 1861, w czasie budowy Kanału Sueskiego, którą opisał w swoim dzienniku. Jego podróż prowadziła przez ośrodki najważniejsze dla miłośnika archeologii - od portu w Aleksandrii, przez Mansurah, Port Said, Kair do upragnionych Teb. Na mapie Tyszkiewicza bajeczne egzotyczne widoki bazarów i pałaców Paszy przeplatają się z historycznymi obrazami starożytnego Egiptu.

Polskiego podróżnika rzadko interesował Egipt spoza baśni i historii. Najważniejsze było to, co kryło się pod ziemią - egipskie zabytki. Hrabia bolał wprawdzie nad rozkradaniem starożytności przez chciwych poszukiwaczy skarbów:

Niebaczność rządu i barbarzyństwo cywilizowanych antykwariuszów europejskich, mocno się ku uszczupleniu tych miłych wrażeń przyczynia. Godne lepszego losu pomniki, niestrzeżone przez nikogo, z dniem prawie każdym coś tracą ze swoich sukni godowych ${ }^{25}$.

Jednak sam ochoczo przyjął mumię, wręczoną mu „na pocieszenie” za to, że nie mógł ukończyć wykopalisk w Tebach.

Podczas gdy podróżnicy odwiedzający egzotyczne ziemie porównywali to, co nieznane, do znajomych obrazów, Kraszewski robił odwrotnie. Porównywał rodzime strony do odległych krain, aby dać do zrozumienia, że dziewiętnastowieczny polski czytelnik wie więcej o odległych miejscach niż o tym, co kryje się w jego własnym kraju. W ten sposób rzeka Styr stawała się Nilem, a Pińsk - litewskim Liverpoolem. Wszystko w myśl zasady wyłożonej na pierwszych stronach Wspomnień...: „Każdy kraj, każdy kątek, każdy człowiek, może być ludziom nauką, artyście wzorem lub pomysłem. [...] Niestety! zawsze szukamy obrazów daleko za sobą, przed sobą, nigdy koło siebie" ${ }^{26}$.

Trasa przedstawiona we Wspomnieniach to wypadkowa tras pięciu podróży. Mapa Kraszewskiego wypełniona jest budzącymi zdziwienie w czytelniku osobliwościami, jak jezioro, które wyrzuca wszystko, co doń wrzucą, wędrująca cerkiew czy gałąź naśladująca ludzką rękę. Te osobliwe przystanki zawdzięczamy literackim źródłom i inspiracjom autora, który wchodził w rolę poety phiolologusa ${ }^{27}$. Powoływał się między innymi na pochodzącego z przełomu XVII i XVIII wieku podróżnika, zoologa i przyrodnika, Gabriela Rzączyńskiego, autora Historia naturalis curiosa Regni Poloniae, Magni Ducatus Lithuaniae XX divisa.

${ }^{24}$ Grzegorz P. Bąbiak, „Podróżnika i kolekcjonera wyprawa do Egiptu (Michał hr. Tyszkiewicz i jego Dziennik podróży...)", in Podróż i literatura, 348.

${ }^{25}$ Michał Tyszkiewicz, Dziennik podróży po Egipcie i Nubii (Paryż: I.K. Wilczyński, 1863), 337.

${ }^{26}$ Józef Ignacy Kraszewski, Wspomnienia..., 3.

${ }^{27}$ Typ poety charakterystyczny dla renesansu i romantyzmu, który pilnie studiuje dzieła dawnych mistrzów. Vide Zygmunt Łempicki, Świat książek $i$ świat rzeczywisty, 357. 
Białe plamy na mapach stanowiły wyzwanie poznawcze dla podróżników. Darwin zapełniał je faktami biologicznymi i geologicznymi. W przypadku Tyszkiewicza białe plamy kryły się już tylko pod ziemią i dotyczyły w większym stopniu historii niż terytorium. $Z$ kolei odkrycie Kraszewskiego polegało na tym, że biała plama nie była w istocie biała. Odkrywając dawne teksty i nadpisując nad nimi nowe, pisarz tworzył ze swojej literackiej mapy palimpsest.

\section{Wyobraźnia}

Widzieliśmy już, jak duże znaczenie w przypadku mapy odgrywała wyobraźnia, która ożywiała zapisy kartograficzne. Jaka była rola wyobraźni w całym procesie pozyskiwania wiedzy?

Podróż i towarzyszące jej zdziwienie w naturalny sposób pobudzały wyobraźnię, nowe wrażenia, doświadczenia, widoki, których wędrowcy nie potrafili jeszcze nazwać, ubierali w szaty literackie, mityczne, historyczne. Wyobraźnia mogła też jednak przysłaniać nowe doświadczenia siatką gotowych skojarzeń i analogii, ulegać niebezpiecznym dla procesu poznania złudzeniom. Tak działo się w przypadku Michała Tyszkiewicza; np. egipskie bazary przywodziły mu na myśl opowiadania Szeherezady. W tych doświadczeniach podróżnika można dostrzec podobieństwo do turystycznych atrakcji opisanych przez Deana MacCannella. Zgodnie z teorią amerykańskiego socjologa, zwiedzający nie widzi oglądanego obiektu, ale zestawia widok $\mathrm{z}$ oznacznikiem ${ }^{28}$. W tym przypadku widokiem byłby autentyczny egipski bazar, a oznacznikiem „opowiadania Szeherezady”, czyli baśnie z Księgi tysiąca i jednej nocy. Tyszkiewicz znał oznacznik wcześniej i oczekiwał, że zobaczy odpowiadający mu widok na miejscu. Nie starał się więc zobaczyć Egiptu takim, jakim jest, ale odnaleźć Egipt znany mu ze świata książek. Ta dominacja romantycznego spojrzenia antycypowała tendencje charakterystyczne dla turystyki masowej, o których pisze Anna Wieczorkiewicz. Badaczka zwraca uwage, że romantyczne zwiedzanie poprzez estetyzację i mieszanie wrażenia $\mathrm{z}$ marzeniem umożliwiało ucieczkę od rzeczywistości ${ }^{29}$. Turystyczny sposób patrzenia nie pozostawiał zbyt wiele miejsca na autentyczne zdziwienie.

We wspomnieniach Kraszewskiego nakładanie siatki wyobraźni na mape zwiedzanych miejsc było strategią pisarską. Fakty historyczne autor mieszał z legendami, przyznając, że tego rodzaju bajki tworzy „niespokojna ciekawość”30.

${ }^{28}$ Dean MacCannell, Turysta. Nowa teoria klasy próżniaczej, trans. Ewa Klekot i Anna Wieczorkiewicz (Warszawa: Muza, 2002), 172-174.

${ }^{29}$ Anna Wieczorkiewicz, Apetyt turysty. O doświadczeniu świata w podróży (Kraków: Universitas, 2008), 104.

${ }^{30}$ Józef Ignacy Kraszewski, Wspomnienia..., 121. 
Tym różnił się od Tyszkiewicza, że informacje o miejscu, które odwiedzał, odkrywał wraz z przestrzenią, po której podróżował. Doświadczał jednocześnie świata rzeczywistego i świata książek.

Wyobraźnia może więc z jednej strony rodzić głód zdziwienia (Kraszewski), z drugiej - przysłaniać nowe doświadczenia, które ma do zaoferowania świat (Tyszkiewicz).

\section{Metoda zbierania/poznania/pisania}

To, co budzi zdziwienie, podróżnik chce przywieźć ze sobą do domu jako obiekt naukowy, trofeum czy po prostu pamiątkę. Proces pozyskiwania obiektów zdziwienia przebiega w różnorodny sposób - od znajdywania, wykopywania i polowania, po obserwowanie i podsłuchiwanie. Czas zająć się kwestią metody - zbierackiej, poznawczej i pisarskiej.

Darwin, zbierając muszle, fosylia i skamieniałości, przyznawał, że znalazł się w miejscu, gdzie „tak dużo dziwów, że miłośnik historii naturalnej nie może prawie chodzić" ${ }^{31}$. Dostrzegał nie tylko osobliwości przyrodnicze, ale też ukryte w nich analogie czy dziwne pokrewieństwo między np. gatunkami grzybów i drzew ${ }^{32}$.

Jeśli badacz chciał w swojej kolekcji oddać cały świat przyrody, musiał przystąpić do polowania, aktu, który Beata Mytych za Carlo Ginzburgiem uważa za źródło XIX-wiecznego „paradygmatu oznaki”, łączącego postać myśliwego z detektywem, lekarzem czy filologiem - wszyscy oni podążają za tropami w nieznane ${ }^{33}$.

W dzienniku Michała Tyszkiewicza historie polowań zajmują o wiele więcej miejsca niż opisy wykopalisk. Polowania hrabiego zwykle przypominają opis walki rycerza z mitycznym potworem: „Udało mi się nareszcie zbliżyć na metę do ogromnego krokodyla [...] strzeliłem do niego kulą ze stalowym ostrym końcem, i ugodziłem w brzuch potworu" ${ }^{34}$. Ciało krokodyla osuwa się do rzeki i zdobywca zostaje z niczym oprócz opowieści. Tyszkiewicz w innym miejscu narzeka na brak myśliwskich eksponatów: „Doktór tymczasem odbywał polowanie na ponętniejsze dla siebie przedmioty, zbierał do zielnika różne nieznane rośliny, i był ode mnie szczęśliwszym, bo zbiory obfite miał w ręku"35. W eksponacie myśliwskim, którego hrabiemu nie udaje się zdobyć, a którego substytutem pozostaje opis wydarzenia, zamykają się przeróżne znaczenia - od egzotyczności i potworności zwierzęcia, po męstwo i bohaterstwo myśliwego.

\footnotetext{
${ }^{31}$ Karol Darwin, Dziennik naturalisty..., 21.

${ }^{32}$ Ibidem, 192.

${ }^{33}$ Beata Mytych, Poetyka i łowy. O idei dawnego polowania w literaturze polskiej XIX wieku (Katowice: Wydawnictwo Uniwersytetu Śląskiego, 2004), 15-17.

${ }^{34}$ Michał Tyszkiewicz, Dziennik podróży..., 309.

${ }^{35}$ Ibidem, 322.
} 
Pomiędzy obserwowaniem a polowaniem mieści się sekcja - skrajna forma voyeryzmu. Żądza patrzenia, obserwacji, każe spoglądać dalej, tam, gdzie nie sięga ludzkie oko, pod powłokę ciała. U Darwina sekcja jest jednym z etapów poznania. Jego metodę rozpoznajemy już po opisie sekcji schwytanego świetlika: zaciera się postać podróżnika, ton narracji staje się naukowy i bezosobowy. Owad po prostu rozpada się na części. Działa zmysł dotyku obok wzroku. Spod powierzchni tekstu przebija jeden cel, który przyświeca wszystkim działaniom Darwina - poznać przyczynę.

W XIX stuleciu stosunek do zwłok był dwuznaczny - z jednej strony badano ciała coraz dokładniej, sięgano coraz głębiej dzięki takim technikom, jak choćby promienie Roentgena; z drugiej - rozwijała się wrażliwość na śmierć indywidualną oraz lęk przed profanacją zwłok ${ }^{36}$. Opinia publiczna powoli przyzwyczajała się jednak, że przyczyn chorób, ale i zbrodni, należy szukać wewnątrz ludzkiego ciała. Sekcja zaczęła być stosowana jako metoda śledcza, np. w słynnej sprawie Kuby Rozpruwacza ${ }^{37}$. Ciekawe, że tabu związane z traktowaniem zwłok zdawało się mieć termin ważności, co widać po stosunku do mumii egipskich.

W czasie swojej podróży Michał Tyszkiewicz miał okazję odwiedzić dom wicekonsula Lawissona, gdzie był świadkiem oraz aktywnym uczestnikiem spektaklu odwijania trzech mumii. Sam nazwał to wydarzenie „widowiskiem”, na które ściągają bogaci mieszkańcy Kairu. Nasz bohater dostąpił zaszczytu rozwijania mumii:

[...] wydobyte i położone na stole ciało, okręcone żółtymi, płóciennymi pasami, wyglądało jak lalka spowita. Odwinąwszy kilkanaście łokci taśmy, znalazłem w połowie długości ciała siedem skarabeów czyli żuków [...] Gdy podniosłem w górę sznurek z nawleczonymi nań skarabeami, ażeby je pokazać obecnym, zbutwiała przędza rozpadła się na kawałki i żuki się rozsypały ${ }^{38}$.

Scena ujawnia, jak wiele wspólnego paranaukowe wydarzenia miały z rozrywką. Gdy Tyszkiewicz porównuje mumię do lalki, czytelnik, podążając za tą analogią, wyobraża sobie hrabiego jako prestidigitatora: zwróćmy uwagę, jak prezentuje widzom to, co znalazł wewnątrz mumii. Pojawia się nawet element akcji, kiedy rozsypują się pokryte hieroglifami skarabeusze. Tajemnice starożytnych zderzają się z kruchością materii, tworząc atrakcyjne widowisko, podczas którego zdziwienie jest produkowane na potrzeby turystycznej ciekawości.

$\mathrm{Z}$ kolei podstawową metodą zbieracką Kraszewskiego było przedłużenie obserwacji o słuchanie i wsłuchiwanie się. Jego wspomnienia zostały zlepione

${ }^{36}$ Alain Corbin, „Miejsce trupa”, in Historia ciała, vol. 2: Od Rewolucji do I wojny światowej, ed. Alain Corbin, trans. Krystyna Belaid i Tomasz Strużyński (Gdańsk: słowo/obraz terytoria, 2013), 219-223.

${ }^{37}$ Elizabeth Klaver, Sites of autopsy in Contemporary Culture (New York: State University of New York Press, 2005), 16-17.

${ }^{38}$ Michał Tyszkiewicz, Dziennik..., 227-228. 
nie tylko z obserwacji przestrzeni, ale przede wszystkim z historii zasłyszanych lub przeczytanych. Opisując mijane miejscowości wołyńskie, wspominał etymologie ich nazw. Jedną z nich są na przykład Skoczyszcze, których historię poznał z opowieści Kozaka. Okazało się jednak, że język literacki jest niewystarczający do opisania ludowej historii: „Cały poemat a przynajmniej piękny śpiew, by można uszyć z tego podania; lecz żeby był zupełnie pięknym, trzeba by go pisać językiem tutejszym, gminnym" 39 .

Kraszewski widział źródło ludowych historii w zażyłości ludzi z naturą, ale również w ludowej ciekawości i sposobie myślenia: „Otaczające Pińsk błota nad Piną i Jasiodłą, mnóstwo rzek i rzeczułek przerzynających je, dały powód jednej z najosobliwszych bajek, jakie kiedy stworzyć mogła domyślność ludzka i niespokojna ciekawość" ${ }^{40}$. W sieć zasłyszanych baśni i legend pisarz wikłał również fakty historyczne i naukowe, np. opisując Styr podawał, że naturaliści „bajają o perłach”, by za chwilę samemu wspomnieć o rogu jednorożca.

\section{Kolekcjonując ludzi}

Podsumowując swoją podróż, Darwin zauważył, że największe zdziwienie budzą $\mathrm{w}$ nim tubylcy ${ }^{41}$. Spotkanie $\mathrm{z}$ innym stanowiło najważniejsze doświadczenie w czasie podróży. Człowiek okazał się największą anomalią, która może zburzyć porządek świata.

Każdy podróżnik zostaje postawiony w paradoksalnej sytuacji, kiedy sam jest obcym, a jednocześnie na swojej drodze spotyka obcego. Tego rodzaju spotkanie jest doświadczeniem radykalnej formy obcości, o której Bernhard Waldenfels pisze:

Dotyczy ona tego wszystkiego, co pozostaje poza wszelkim porządkiem i stawia nas wobec wydarzeń, które podają w wątpliwość nie tylko jakąś określoną interpretację, lecz samą możliwość interpretacji. Należą tu takie fenomeny graniczne, jak erotyka, upojenie, sen czy śmierć, które przełamują bieg rzeczy, także porządek czasu i przestrzeni, zacieśniając się w jedną chwilę, ocierając się o bezczasowość i bezprzestrzennośćc ${ }^{42}$.

Kraszewski dostrzegł, że nawet w przestrzeni swojskiej można spotkać obcego, o którym niewiele wiemy i który dotąd nie stanowił dla podróżujących przedmiotu poznania. Mowa o chłopach. Inteligent-ziemianin przedstawiał bliskie spotkanie z dziewiętnastowiecznym chłopem tak, że przypomina ono zetknięcie z „dzikimi” ludami w czasie dalekich podróży. Pisarz często porównywał swoich

${ }^{39}$ Józef Ignacy Kraszewski, Wspomnienia..., 24.

${ }^{40}$ Ibidem, 121.

${ }^{41}$ Karol Darwin, Podróż naturalisty..., 410.

${ }^{42}$ Bernhard Waldenfels, Topografia obcego, trans. Janusz Sidorek (Warszawa: Oficyna Naukowa, 2002), 34. 
bohaterów do „dzikich”, np. kiedy pisał o Pińczukach: „Chłopi tutejsi szczerze mówiąc, nie mają wysokiej reputacji i rozumu, oni swój Pińsk, jak Chińczycy Pekin, za środek świata przywykli uważać, przez pół roku utrudnione mając zalewem związki z resztą świata, w pół dziko żyją"³.

Pisarz uczynił różne aspekty życia chłopów poleskich obiektem naukowego poznania. Wprowadził nawet na poły ironiczną klasyfikację gospodarzy, dzieląc ich na gospodarzy starozakonnych, gospodarzy na dwóch krzesłach i neo-gospodarzy. Tą typologią zwracał uwagę nie tylko na zapóźnienie cywilizacyjne i odosobnienie, ale i specyfikę kultury oraz zwyczaje miejscowej ludności. Chłopi są zresztą głównym bohaterem Wspomnień... To ich opowieści, zwyczaje, domy stoją na pierwszym planie rysowanych przez Kraszewskiego obrazów. Obrazy te powstawały w bezpośrednim doświadczeniu wędrowca, który postępuje mało znanymi szlakami lub wręcz przeciera drogi.

Kiedy Tyszkiewicz wyruszał do Egiptu, okrzepła już nieco nowość „dzikich” ludów. Archiwum kultury, z którego korzystali wędrowcy, wzbogaciło się o liczne opisy spotkania $z$ obcym, wpisujące ludzi innych kultur w przeróżne mity - Orientu, Czarnej Afryki itd. Bagaż ten szczególnie dał o sobie znać w relacji Tyszkiewicza, który przypisywał Egipcjanom takie cechy, jak szaleństwo, rozbudzony erotyzm czy fantazja: „Na Wschodzie, gdzie klimat, urządzenie społeczne i sama nawet religia działają mocno na rozwinięcie wyobraźni ze szkodą zimnego rozsądku, ciche obłąkanie, sen nieprzespany umysłu, daleko częściej się zdarza niż w Europie" ${ }^{44}$. Wpływ klimatu na psychikę był wszak analizowany przez wielu ówczesnych uczonych, pisał o tym m.in. Hipolit Taine w Historii literatury angielskiej czy Cesare Lombroso w pracy Geniusz i obłakanie.

Dla Tyszkiewicza inność Egipcjan miała wymiar przede wszystkim malowniczy, dodający kolorytu obrazowi „cudownego” Egiptu. Był to obraz charakterystyczny dla zachodniego pojmowania Orientu, badacze często wyruszali w podróż z takim gotowym konstruktem ${ }^{45}$. Ludzie stawali się tu ornamentem na fantastycznym fresku: „Ustawiczne ścieranie się dwóch pierwiastków cywilizacji, ruchawość i przemysłowość Europy, obok spoczynku i słonecznej fantazji Afryki, ma w sobie coś dziwnie uroczego, godnego pędzla artysty" ${ }^{46}$. Relację Tyszkiewicza przenika egzotyka o funkcji ewazyjnej ${ }^{47}$, czyli spełniającej potrzeby zmysłowe podróżnika, bo otwierającej przed nim fascynującą przestrzeń Orientu, do której może uciec przed codzienną nudą. Oczywiście tego rodzaju egzotyzacja nie jest źródłem poznania, ale przyjemności.

${ }^{43}$ Józef Ignacy Kraszewski, Wspomnienia..., 133.

${ }^{44}$ Michał Tyszkiewicz, Dziennik podróży..., 75.

${ }^{45}$ Zob. Edward Said, Orientalizm, 94.

${ }^{46}$ Michał Tyszkiewicz, Dziennik podróży..., 128-129.

${ }^{47}$ Zob. Erazm Kuźma, „Semiologia egzotyki”, in Miejsca wspólne. Szkice o komunikacji literackiej $i$ artystycznej, ed. Edward Balcerzan i Seweryna Wysłouch (PWN, Warszawa, 1985), 313-314. 


\section{Spotkanie z niewyjaśnionym}

„Nikt nie odpowiada - tu wszystko zdaje się wieczne. Dzikość ma swój język tajemniczy: uczy ona podziwiać i wątpić" ${ }^{48}$ - ten cytat z Shelleya, przytoczony przez Darwina w jego dzienniku, dobrze oddaje doświadczenie zdziwienia w podróży. Spotkanie z niewyjaśnionym, z anomalią, która przeczy wszystkiemu, co dotąd znane, sprawia, że zdziwienie przechodzi w podziw i zwątpienie, które umożliwiają rozpoznanie nowego porządku rzeczy. Jakim językiem przemawia do podróżników tajemnica ${ }^{49}$ ?

Przede wszystkim zjawiska niesamowite wymagają uwiarygodnienia, nie wystarczy to, że było się naocznym świadkiem. Dziwność opowieści może być powodem, dla którego ten, kto doświadczył osobliwego, woli milczeć. Może to dotyczyć nie tylko wędrowca, ale także tubylców, niechętnie otwierających się przed obcym. Narzekał na to Kraszewski jako zbieracz osobliwości ludowych:

Lecz ta cząstka ze skarbnicy ludu, podań i pieśni, o które tak trudno dopytać milczącego wieśniaka, lękającego się dla swoich skarbów uśmiechu niedowiarstwa i pogardy - skarbu, który tylko w wieczornicach i doświtkach pokolenia pokoleniom podają - ożywiła mój umysł, i tysiąc napędziła marzeń ${ }^{50}$.

Kraszewski-pisarz dziwił się inaczej niż Kraszewski-badacz. Szukał w historii prawdy uniwersalnej, a nie faktu, który będzie mógł potwierdzić. Tajemnica i niezwykłość, które budzą zdziwienie, były inspiracją dla jego wyobraźni.

Tyszkiewicz podawał w wątpliwość doniesienia o znajdowaniu w ciałach mumii żywych roślin sprzed tysięcy lat - wspominał o znanym przypadku pszenicy i cebuli. Archeolog, skoro sam nie potwierdził tych faktów, nie do końca wierzył w ich prawdziwość:

Bez wątpienia, tajemnicza siła życia nie jest do tyla poznaną, ażeby można było twierdzić z pewnością, że nie ma dosyć mocy przetrwać nieskazitelnie w nasieniu lat tysiąc, skoro kilka trwać może. Ale na to potrzeba stanowczych i wielokrotnych dowodów; uczeni mogli być albo sami oszukani, albo niewinnie oszukiwać mogli innych ${ }^{51}$.

Mimochodem zwracał uwagę na to (podobnie jak Darwin), że najważniejszą z tajemnic jest tajemnica życia, jego genezy i możliwości.

${ }^{48}$ Karol Darwin, Podróż naturalisty..., 136.

${ }^{49}$ Tajemnicę z cytatu Shelleya można interpretować jako element doświadczenia metafizycznego. W tym kontekście adekwatne mogłyby się okazać kategorie wprowadzone przez Rudolfa Otto: misterium tremendum i fascinans. Interesują mnie jednak przede wszystkim tajemnice, które przedstawieni autorzy mają nadzieję rozwikłać. Nie mieszczą się więc one w sferze religijnej tajemniczości obejmującej to, co niepojęte i tak inne, że niemożliwe do zrozumienia. Zaprezentowane tu tajemnice nie są prawdziwym misterium tremendum, ale tym, co Otto nazywa „zwykłym mirum”, a więc rzeczą lub stanem, który dziwi. Cf. Rudolf Otto, Świętość, trans. Bogdan Kupis (Wrocław: Thesaurus Press, 1933), 50.

${ }^{50}$ Józef Ignacy Kraszewski, Wspomnienia..., 186.

${ }^{51}$ Michał Tyszkiewicz, Dziennik podróży..., 230. 
Otwarcie się na przyjęcie tajemnicy ułatwiają doświadczenia graniczne - jak spotkanie z Obcym, ale też niecodzienne przeżycia, jednym słowem to, co budzi zdziwienie. Dla Darwina takim doświadczeniem było trzęsienie ziemi, dla Tyszkiewicza - fatamorgana:

Po kwadransie drogi ku jezioru, krajobraz wznosząc się coraz wyżej, zawisnął na błękicie, a przed nami na ziemi pozostało tylko niezmierne wód zwierciadło. Uroczysty był to widok tego uduchowienia kształtów materii [...] jeszcze gotów byś wierzyć, iż to nie złudzenie, lecz wniebowzięta rzeczywistość. Oko Europejczyka, nienawykłe do widoku podobnych zjawisk, tonie w nich $\mathrm{z}$ rozkoszą trudną do opisania ${ }^{52}$.

Tyszkiewicz pod wpływem zdziwienia niezwykłym zjawiskiem przyrodniczym nie tylko otwierał się na nowe doznania, ale też czerpał z tego przyjemność.

\section{Od zdziwienia do porządkowania: czas}

Mnogość doświadczeń, które budzą zdziwienie, wymaga od podróżnika uporządkowania, nadania im sensu. Spośród wielu możliwych porządków na pierwszy plan wysuwa się porządek czasu. To czas, obok przestrzeni, należy do podstawowych kategorii rządzących drogą wędrowca. Objawia się to już w samej formie opisu podróży - od dziennika najbardziej osadzonego w teraźniejszości, po wspomnienia, które polegają na wejrzeniu w minione.

Porządek czasu jest bardzo wyraźnie zaznaczony w dzienniku Tyszkiewicza. Nie mogło być inaczej w przypadku archeologa: Tyszkiewicz dokonywał rekonstrukcji. Widzimy to zarówno w języku, kiedy pisał o zabytkach rozrzuconych niczym kości czy o cmentarzach garnków, jak i w opisie najważniejszego dla niego doświadczenia Teb: „Wszystko, co się kiedykolwiek czytało lub słyszało o tym „stubramnym” Homerowym grodzie [...], wszystko to rozogniona wyobraźnia przywodzi na pamięć, ożywia i każe snuć przed oczami jak na jawie"53. Tyszkiewicz posługiwał się również wyobraźnią, by przywrócić do życia ruiny, skorupy i mumie.

Porządkowanie przez czas mogło więc polegać na rekonstruowaniu, ale też, jak pokazuje tekst Kraszewskiego, na konstruowaniu: mieszaniu i nakładaniu porządków kroniki, historii ludowej, historii rodów, historii oficjalnej i cudownych podań - wszystkie współtworzą wewnętrzny czas palimpsestowego wspomnienia, na które złożyło się pięć podróży.

\section{Zbiory}

Zainteresowania i odkrycia przedstawionych tu podróżników bardzo różnią się między sobą: Tyszkiewicz badał podziemne skarby Teb, Kraszewski odczytywał chłopskie hieroglify. Ta różnica przełożyła się na różnicę między zbiorami,

\footnotetext{
${ }^{52}$ Ibidem, 48, 49.

${ }^{53}$ Michał Tyszkiewicz, Dziennik podróży..., 342.
} 
które były pokłosiem wędrówek. Wpłynęła ona też na zastosowany przez podróżników model poznawczy. Tyszkiewicza, jako archeologa, dziwiły przede wszystkim starożytne artefakty, które umożliwiały rekonstrukcję świata minionego. Kraszewski łączył w swojej relacji perspektywę antropologa, archeologa i artysty, badał jednocześnie naturę i kulturę, korzystając z bezpośredniej obserwacji, rozmowy, odnalezionej historii czy opowieści.

Wśród obiektów, które nasi autorzy uważali za budzące zdziwienie, znajdują się ludzie, rzeczy, rośliny i zwierzęta. Stanowiły one dla nich przedmiot poznania, znak, który odsyłał do ogólnej prawdy. Poznanie dokonywało się na styku różnych źródeł (obserwacje naukowe współwystępowały z legendami i baśniami lub z zastanymi relacjami poprzedników) i różnych sposobów ich wykorzystania (precyzyjny opis mieszał się z powabną analogią). To sprawiło, że teksty podróży mają cechy gabinetów osobliwości. Ludzie, zwierzęta i rzeczy przedstawione są jako dziwy, które z jednej strony stanowią obiekt poznania, a z drugiej podlegają zabiegom personifikacji, animizacji i reifikacji, by mogły opowiadać własne historie i tworzyć nowe obrazy świata.

Największe zdziwienie budziło w podróżnikach spotkanie z nieznanym, które odsłaniało istotny cel podróży: rozwikłanie tajemnicy. Mogła to być tajemnica życia, przestrzeni czy natury. Żeby ją opisać, trzeba było posłużyć się specjalną poetyką, która umożliwiłaby wywołanie efektu zdziwienia u czytelnika. Autorzy uzyskiwali go najczęściej przez niezwykłą analogię, mityzację czy egzotyzację obiektu poznania. Trudniejszym zadaniem pisarskim był kolejny etap: jak opisać nieznane? Najprostszym rozwiązaniem były naturalnie porównania: nieznane opisywano poprzez znajome. Można było też zapożyczyć język innego, przytoczyć jego historie.

Przedstawione tu przestrzenie zdziwienia nie zależały od szerokości geograficznej, ale od otwartości umysłu podróżnika. Wypełniły je osobliwości, na podstawie których żywa wyobraźnia mogła wysunąć śmiałe hipotezy naukowe i które tworzyły fundamenty nowego obrazu świata.

\section{SPACE OF WONDER IN THE TRAVEL WRITING \\ OF MICHAŁ TYSZKIEWICZ AND JÓZEF IGNACY KRASZEWSKI}

Sum m a ry

Many researchers call the nineteenth century yet another epoch of geographic discoveries. Travel was associated with the development of knowledge and treated as a cognitive adventure. This article attempts to reconstruct the process of cognition described by Michał Tyszkiewicz and Józef Ignacy Kraszewski in their travel writings. I assign primary importance to the category of wonder. The article tries to find out what astonished travelers and how this kind of wonder influenced the image of the world they created. 